\title{
Research on Relationship between Financial Inclusion and Economic Growth of Rwanda: Evidence from Commercial Banks with ARDL Approach
}

${ }^{1}$ Moïse Bigirimana, ${ }^{2}$ Xu Hongyi

\author{
${ }^{2}$ School of Management, Wuhan University of Technology, PR China \\ ${ }^{1}$ School of Economics and Business Studies, Kigali Independent University ULK, Rwanda
}

\begin{abstract}
This study examines the relationship between financial inclusion and economic growth of Rwanda using annual data from 2004 to 2016. We used ARDL as it is a new approach to the problem of testing the existence of a level relationship between a dependent variable and a set of regressors, when it is not known with certainty whether the underlying regressors are trend- or first-difference stationary as developed by Pesaran. The results of our study revealed that there is long-run relationship between financial inclusion and economic growth of Rwanda.
\end{abstract}

Keywords: Financial inclusion, Economic growth, Commercial bank, ARDL

\section{Introduction}

The government of Rwanda has got rapid growth since 2000 and has set vision 2020 where service industry was given more emphasis to boost economic growth. It is in this line that they have set a target of having $90 \%$ of Rwandans financially included by the year 2020. Different strategies were put in place to increase financial inclusion in Rwanda. Among these strategies, we can mention licensing different foreign commercial banks and creating SACCOs for each sector among 416 sectors in Rwanda. It is of great importance for researchers to know whether the efforts that the government of Rwanda has put in yielded results. It is in this context that we have conducted this research about financial inclusion and economic growth of Rwanda. Although financial inclusion has become topical on the global policy agenda for sustainable development, economic literature on financial inclusion is still in its infancy (Park \& Mercado, 2015).

When measuring access and use of financial services two indicators were used by Beck et al (2007) i.e the number of branches and ATMs per capita and per square kilometer for 89 countries(Beck, Demirguc-Kunt, \& Martinez Peria, 2007). This poses a problem as the size of countries vary. A small country may show a good number of ATMs per kilometer just because it is small. The number of branches may be big for a big country and still more people do not have access. This research considers only one country to facilitate use of more indicators and show the real impact of financial institutions on financial inclusion and the relationship between financial inclusion and economic growth in Rwanda.

\section{Literature Review}

Different authors have defined financial inclusion as being able to get access to formal financial institutions or using financial services. See (Bayero, 2015; Naceur et al., 2015; Zins \& Weill, 2016; Diniz, Birochi, \& Pozzebon, 2012). 
On this basis, the role played by commercial banks is worthy to discuss. Research has shown that banks increase growth (Chakraborty \& Ray, 2006). Financial intermediation promotes growth (Bencivenga \& Smith, 1991). What is amazing is that some researches show that that tighter bank competition enhances the occurrence of bank failures. Thus, measures that increase bank competition could undermine financial stability (Fungáčová \& Weill, 2013). Again, microfinance loans reduce poverty and foster economic growth (Berhane \& Gardebroek, 2011), micro-loans increase employment (Baldi, Guido and Sipilova, 2014). (Liang \& Reichert, 2012) concluded that that growth in NBFIs has a statistically significant negative impact on economic growth. Vaithilingam, Guru, \& Shanmugam (2003) found that an increase in commercial bank loans to the private sector has a direct effect on real income. According to (Mandel \& Seydl, 2016) loan supply exerts a notable drag on economic activity. Not only ordinary banks contribute to economic growth but also Islamic banks Daly \& Frikha (2016). Most recently, Kim, Yu, \& Hassan (2018) found that financial inclusion has a positive effect on economic growth. It is evidenced by many authors that financial inclusion is of paramount importance. Demirgüc-Kant \& Klapper (2012) said that inclusive financial systems benefit poor people and other disadvantaged groups. Mandel \& Seydl (2016) showed that financial inclusion contributes positively to financial stability.

It is important to highlight what literature says about financial inclusion and economic growth. Most researchers have focused on role financial development on economic growth rather than financial inclusion and economic growth. For example, (Claessens \& Laeven, 2003) show that financial development contributes to economic growth. They share the share the view with many authors who agreed that financial development causes economic growth ,see (Shahbaz, Rehman, \& Muzaffar, 2015; Sehrawat \& Giri, 2012; Shahbaz \& Mafizur Rahman, 2014; Anwar \& Sun, 2011).

Masoud \& Hardaker (2012) emphasized that stock market development (as part of financial development) has a significant effect on economic growth. Valickova, Havranek, \& Horvath (2015) also showed that stock markets support faster economic growth than other financial intermediaries. Durusu-Ciftci, Ispir, \& Yetkiner (2016) showed that debt from credit markets and equity from stock markets are two long-run determinants of GDP per capita. According to R. King \& Levine (1993), at the cross-country level, evidence indicates that various measures of financial development (including assets of the financial intermediaries, liquid liabilities of financial institutions, domestic credit to private sector, stock and bond market capitalization) are robustly and positively related to economic growth. Shan, Morris, \& Sun (2001) also said that there is little support for the hypothesis that finance "leads" growth, and caution must be exercised in making general conclusions about this relationship. Rousseau \& D'Onofrio (2013) found unidirectional links from financial development to measures of real activity for about twothirds of Sub Saharan African countries.

According to Sehrawat \& Giri (2016) financial development and economic growth cause ruralurban income inequality. Financial inclusion is complementary to economic growth as the two contribute toward poverty alleviation (Onaolapo, 2015). Literature shows that access to finance is associated with faster growth (Beck, DemirgüÇ-Kunt, \& Maksimovic, 2005). These differences in findings and need for focus on financial inclusion motivated us to conduct a research on financial inclusion and economic growth.

\section{Methodology}

The study takes into consideration 13 years from 2004 to 2016 . Three dimensions of financial inclusion were used to measure financial inclusion. These are access, penetration and usage as they are recommended by many authors as indicators of financial inclusion. This refers to Global financial inclusion database (Demirguc-Kunt, Klapper, Singer, \& Van Oudheusden, 2015) as 
these dimensions are used.Also, Kodan \& Chhikara (2013), show specific measurements of financial inclusion, where depth or penetration was measured by bank accounts per 1,000 population; availability has been measured by the number of bank branches and number of ATMs per 100,000 people; and usage is measured by volumes of credit plus deposit related to the gross domestic product (GDP). The same dimensions were used by Sharma (2016) in Nexus between financial inclusion and economic growth: evidence from the emerging Indian economy and Sarma (2008) in index of financial inclusion. In this research, Automated teller machines per 100,000 adults people and \% of branches of commercial banks per 1,000 km2were used as proxies of Access. $\%$ of deposit accounts with commercial banks per 1,000 adults were used as proxy of penetration and Outstanding deposits with commercial banks ( $\%$ of GDP) along with Outstanding loans with commercial banks (\% of GDP) were used as proxies of usage. GDP was used as a proxy of economic grow th. The described dimensions are relation to commercial banks as part of financial inclusion. These dimensions are used to study the relationship between financial inclusion and economic growth.

\subsection{Econometric Model}

$\log G D P=\mu+\mu 1 \log A T M K M+\mu 2 \log A T M A D+\mu 3 \log B R A K M+\mu 4 \log B R A D+\mu 5 \log D E P A D+\mu 6 \log L A C$ $A D+\mu 7 \log O T D P+\mu 8 \log O T L+\epsilon$

Where:

ATMK stands for Automated Teller Machines per 1,000 km2

ATAMAD : Automated Teller Machines per 100,000 adults

BRAKM : Branches of commercial banks per $1,000 \mathrm{~km} 2$

BRAD : Branches of commercial banks per 100,000 adults

DPAD : Deposit accounts with commercial banks per 1,000 adults

LACAD : Loan accounts with commercial banks per 1,000 adult

OTDP : Outstanding deposits with commercial banks (\% of GDP)

OTL : : Outstanding loans with commercial banks (\% of GDP)

GDP : Gross Domestic Products

$\mu, a, \beta$ are constants

$€$ : Error term

\section{Results and Discussion}

Unit root test shows that all the variables were stationary at the level or first difference (at $5 \%$ and $10 \%$ ). The pre-condition of running co-integration the unit root of variables must be checked. Following this prerequisite condition, it is necessary that data should be stationary. The variables which are not stationary at level are made stationary after taking 1st difference as they are expected to be stationary of first order. But it is not necessary that all series for which null hypothesis of unit root is accepted may be integrated of first order. The lag len gth was selected by Akaike Information Criteria (AIC). The variables analyzed for stationarity are Gross Domestic Product(GDP), Automated Teller Machines per 1,000 km2 (ATMKM), Automated Teller Machines per 100,000 adults(ATMD), Branches of commercial banks per 1,000 km2(BRAKM), Branches of commercial banks per 100,000 adults(BRAD), Deposit accounts with commercial banks(DPAD), Deposit accounts with commercial banks per 1,000 adults(), Loan accounts with commercial banks per 1,000 adults (LACD), Outstanding deposits with commercial banks (\% of GDP)( OTDP), Outstanding loans with commercial banks (\% of GDP)( OTL).The null hypothesis of all the unit root tests performed state the existence of unit root, the alternative hypothesis state the absence of it. The results are derived by using Eviews 9 . Following detailed performed tests are given further: Unit roots tests are performed with ADF tests.

Because of mixture of first and second difference, we are allowed to use ARDL. This technique was selected for two main reasons: First, it is effective in executing the short-and long-term relationships between the different variables that do not have the same order of integration, 
provided that such variables are stationary in level; I (0), and/or they are stationary in the first difference; I (1). Second, the ARDL approach can remove the problems associated with omitted variables and auto-correlation. Third, it can be useful for a small sample size application. The same reason is shared by other researchers such as Adel \& Imen (2018) and Shahzad, Jan, Ali, \& Ullah (2018).

We used ARDL as it is a new approach to the problem of testing the existence of a level relationship between a dependent variable and a set of regressors, when it is not known with certainty whether the underlying regressors are the trend-or first-difference stationary (Pesaran, Shin, \& Smith, 2001).This has been used widely by different as it is the best and new approach(Goh, Sam, \& Mcnown, 2017; Tursoy \& Faisal, 2017; Bildirici \& Ozaksoy, 2017; Murthy \& Okunade, 2016).

The results of ARDL, the bound test for co-integration test reveals that there is long run relationship between Gross Domestic Product, Automated teller Machines per adult people, Automated teller Machines per square km, Bank branches per adult people, Branches per square $\mathrm{km}$, deposits accounts per adults people, loan accounts per adults people, Outstanding loans, and Outstanding deposits per adults people at 5percent level of significance. F-statistic of 6.100343 is bigger than the upper bound critical value of 3.97 ; therefore the null hypothesis of no co-integration is rejected at $1 \%$ level of significance which testifies the presence of the longrun relationship between GDP and all the explanatory variables.

Based on the results of ARDL bounds test, all the variables jointly affect the dependent variable at $1 \%$ in long-run. Note that in the short-run the following variables are significant: deposit accounts per adults people, branch per square $\mathrm{km}$, branches per adults people, loan accounts per adults people, outstanding deposits per adults people and outstanding loans. Automated teller machines per square $\mathrm{km}$ and branches per square $\mathrm{km}$ are not significant but, we hope that they can be adjusted quarterly as error correction term has the negative sign.

Table 1: ARDL Bounds Test

\begin{tabular}{|l|l|l|}
\hline Date: 01/11/18 Time: 19:04 \\
\hline Sample: 2004Q2 2016Q4 \\
\hline \multicolumn{2}{|l|}{ Included observations: 48} \\
\hline \multicolumn{2}{|l|}{ Null Hypothesis: No long-run relationships exist } \\
\hline Test Statistic & \multicolumn{1}{l|}{ Value } & $\mathrm{K}$ \\
\hline F-statistic & 6.100343 & 9 \\
\hline Critical Value Bounds & I1 Bound \\
\hline Significance & I0 Bound & 2.99 \\
\hline $10 \%$ & 1.88 & 3.3 \\
\hline $5 \%$ & 2.14 & 3.6 \\
\hline $2.5 \%$ & 2.37 & 3.97 \\
\hline $1 \%$ & 2.65 & \\
\hline
\end{tabular}

Table 2: ARDL Cointegrating short and Long Run Form

Dependent Variable: LGDP1

Selected Model: $\operatorname{ARDL}(1,1,1,1,0,0,1,1,1)$ 


\begin{tabular}{|c|c|c|c|c|}
\hline \multicolumn{3}{|c|}{ Date: $10 / 31 / 17$ Time: $16: 09$} & & \\
\hline \multicolumn{5}{|c|}{ Sample: 2004Q1 2016Q4 } \\
\hline \multicolumn{5}{|c|}{ Included observations: 49} \\
\hline \multicolumn{5}{|c|}{ Cointegrating Form/short run } \\
\hline Variable & Coefficient & Std. Error & t-Statistic & Prob \\
\hline $\mathrm{D}($ LDPAD1) & 0.731015 & 0.119795 & 6.102214 & 0.0000 \\
\hline D(LBRAKM1) & -23.674638 & 5.001460 & -4.733545 & 0.0000 \\
\hline D(LBRAD1) & 22.245989 & 4.968371 & 4.477522 & 0.0001 \\
\hline D(LATMKM1) & -3.166591 & 2.032566 & -1.557928 & 0.1288 \\
\hline D(LATMD1) & 3.025058 & 2.042550 & 1.481020 & 0.1481 \\
\hline $\mathrm{D}($ LLACD1) & 0.761805 & 0.103269 & 7.376910 & 0.0000 \\
\hline D(LOTDP1) & 0.258018 & 0.079300 & 3.253694 & 0.0026 \\
\hline $\mathrm{D}($ LOTL1) & 2.816872 & 0.354145 & 7.954011 & 0.0000 \\
\hline CointEq(-1) & -0.087853 & 0.065349 & -1.344359 & 0.1880 \\
\hline \multicolumn{5}{|c|}{ Long Run Coefficients } \\
\hline Variable & Coefficient & Std. Error & t-Statistic & Prob. \\
\hline LDPAD1 & 2.252500 & 1.733795 & 1.299173 & 0.2029 \\
\hline LBRAKM1 & -6.383135 & 20.661505 & -0.308939 & 0.7593 \\
\hline LBRAD1 & 2.150652 & 20.722928 & 0.103781 & 0.9180 \\
\hline LATMKM1 & -36.044160 & 31.704339 & -1.136884 & 0.2638 \\
\hline LATMD1 & 34.433133 & 31.050382 & 1.108944 & 0.2755 \\
\hline LLACD1 & 4.119077 & 2.832496 & 1.454222 & 0.1553 \\
\hline LOTDP1 & 1.754153 & 1.462681 & 1.199272 & 0.2390 \\
\hline LOTL1 & 4.842998 & 2.619126 & 1.849089 & 0.0734 \\
\hline $\mathrm{C}$ & 11.929335 & 8.707051 & 1.370078 & 0.1799 \\
\hline
\end{tabular}

ARDL results generated the following equation:

LGDPt $=11.9293+2.2525 *$ LDPADt $^{-}-6.3831 *{ }^{2}$ LBRAKMt $+2.1507 *$ LBRAD $^{-}$

$36.0442 *$ LATMKMt+34.4331*LATMDt $+4.1191 * L L A C D_{t}+1.7542 *{ }^{2} O T D P_{t}+4.8430 *{ }^{2} O T L_{t}$

\subsection{Results of Pair Wise Granger Causality Test}

The significance level is at 5\% and $10 \%$ and we are only interested in knowing the causality between dependent and independent variables. To investigate the causal relationship between two variables with the help of Granger causality test, the above table shows the following: Granger causality test showed the following results: Loan Accounts per Adults People (LACAD) does not Granger cause Gross domestic Product(GD)P versus GDP does not Granger cause LACAD. Since P-value (.0029) is less than .05 we conclude that causality runs from GDP to LACAD. Meaning that direction of causality runs from GDP to LACAD. But LACAD does not Granger cause GDP in Rwanda as associated P-value is not significant.

Outstanding loans does not Granger cause Gross Domestic product versus Gross Domestic product does not Granger cause Outstanding loans showed unidirectional causality where Outstanding loans Granger cause Gross Domestic Products. The above findings are in line with what theories show that loans positively affect economic growth. For example, Du (2011) found that the increase in the supply of long-term loans can promote the economic growth. On the other hand, Donou-Adonsou \& Sylwester (2017) found no relationship between commercial banks loans and raise in economic growth.

Our study reveals that Loan Accounts per Adult People granger causes outstanding deposits and that deposit does not Granger cause loan accounts. The results of our study are contrary to 
Research on Relationship between Financial Inclusion and Economic Growth of Rwanda: Evidence from

Commercial Banks with ARDL Approach

findings of Boukhatem \& Ben Moussa (2018) which revealed that deposits are likely to increase the scale of loans in MENA countries.

Our study reveals that there is bidirectional causality between deposits accounts and branches per square $\mathrm{km}$. Note that nonsignificant values are omitted.

Table 3: Pairwise Granger Causality Tests

\begin{tabular}{|c|c|c|c|}
\hline \multicolumn{4}{|l|}{ Date: $10 / 31 / 17$ Time: $16: 36$} \\
\hline \multicolumn{4}{|l|}{ Sample: 2004Q1 2016Q4 } \\
\hline \multicolumn{4}{|l|}{ Lags: 2} \\
\hline Null Hypothesis: & Obs & F-Statistic & Probability \\
\hline LDPAD1 does not Granger Cause LGDP1 & 47 & 1.77562 & 0.1819 \\
\hline \multicolumn{2}{|l|}{ LGDP1 does not Granger Cause LDPAD1 } & 1.29369 & 0.2850 \\
\hline LBRAKM1 does not Granger Cause LGDP1 & 50 & 1.70226 & 0.1938 \\
\hline \multicolumn{2}{|l|}{ LGDP1 does not Granger Cause LBRAKM1 } & 0.47261 & 0.6264 \\
\hline LBRAD1 does not Granger Cause LGDP1 & 50 & 1.58930 & 0.2153 \\
\hline \multicolumn{2}{|l|}{ LGDP1 does not Granger Cause LBRAD1 } & 0.47810 & 0.6231 \\
\hline LATMKM1 does not Granger Cause LGDP1 & 49 & 2.09187 & 0.1356 \\
\hline \multicolumn{2}{|l|}{ LGDP1 does not Granger Cause LATMKM1 } & 0.08713 & 0.9167 \\
\hline LATMD1 does not Granger Cause LGDP1 & 49 & 2.04299 & 0.1418 \\
\hline \multicolumn{2}{|l|}{ LGDP1 does not Granger Cause LATMD1 } & 0.08890 & 0.9151 \\
\hline LLACD1 does not Granger Cause LGDP1 & 50 & 1.95496 & 0.1534 \\
\hline \multicolumn{2}{|l|}{ LGDP1 does not Granger Cause LLACD1 } & 6.68661 & 0.0029 \\
\hline LOTDP1 does not Granger Cause LGDP1 & 50 & 1.28310 & 0.2871 \\
\hline \multicolumn{2}{|l|}{ LGDP1 does not Granger Cause LOTDP1 } & 0.14794 & 0.8629 \\
\hline LOTL1 does not Granger Cause LGDP1 & 50 & 2.60966 & 0.0847 \\
\hline \multicolumn{2}{|l|}{ LGDP1 does not Granger Cause LOTL1 } & 1.97264 & 0.1509 \\
\hline LBRAKM1 does not Granger Cause LDPAD1 & 47 & 1.34218 & 0.2722 \\
\hline \multicolumn{2}{|l|}{ LDPAD1 does not Granger Cause LBRAKM1 } & 3.79739 & 0.0305 \\
\hline LBRAD1 does not Granger Cause LDPAD1 & 47 & 1.96811 & 0.1524 \\
\hline \multicolumn{2}{|l|}{ LDPAD1 does not Granger Cause LBRAD1 } & 4.96020 & 0.0116 \\
\hline LATMKM1 does not Granger Cause LDPAD1 & 46 & 0.09955 & 0.9055 \\
\hline \multicolumn{2}{|l|}{ LDPAD1 does not Granger Cause LATMKM1 } & 14.1622 & 2.E-05 \\
\hline LATMD1 does not Granger Cause LDPAD1 & 46 & 0.10916 & 0.8968 \\
\hline \multicolumn{2}{|l|}{ LDPAD1 does not Granger Cause LATMD1 } & 14.0563 & $2 . E-05$ \\
\hline LLACD1 does not Granger Cause LDPAD1 & 47 & 0.28679 & 0.7521 \\
\hline \multicolumn{2}{|l|}{ LDPAD1 does not Granger Cause LLACD1 } & 5.35341 & 0.0085 \\
\hline LOTDP1 does not Granger Cause LDPAD1 & 47 & 1.79317 & 0.1789 \\
\hline \multicolumn{2}{|l|}{ LDPAD1 does not Granger Cause LOTDP1 } & 2.86480 & 0.0682 \\
\hline LOTL1 does not Granger Cause LDPAD1 & 47 & 2.29670 & 0.1131 \\
\hline \multicolumn{2}{|l|}{ LDPAD1 does not Granger Cause LOTL1 } & 0.38424 & 0.6833 \\
\hline LBRAD1 does not Granger Cause LBRAKM1 & 50 & 1.72716 & 0.1894 \\
\hline \multicolumn{2}{|l|}{ LBRAKM1 does not Granger Cause LBRAD1 } & 1.64146 & 0.2051 \\
\hline LATMKM1 does not Granger Cause LBRAKM1 & 49 & 0.08087 & 0.9224 \\
\hline \multicolumn{2}{|l|}{ LBRAKM1 does not Granger Cause LATMKM1 } & 10.6890 & 0.0002 \\
\hline LATMD1 does not Granger Cause LBRAKM1 & 49 & 0.07015 & 0.9324 \\
\hline \multicolumn{2}{|l|}{ LBRAKM1 does not Granger Cause LATMD1 } & 10.3105 & 0.0002 \\
\hline LLACD1 does not Granger Cause LBRAKM1 & 50 & 0.13981 & 0.8699 \\
\hline \multicolumn{2}{|l|}{ LBRAKM1 does not Granger Cause LLACD1 } & 4.28129 & 0.0199 \\
\hline LOTDP1 does not Granger Cause LBRAKM1 & 50 & 3.22388 & 0.0492 \\
\hline \multicolumn{2}{|l|}{ LBRAKM1 does not Granger Cause LOTDP1 } & 2.44020 & 0.0986 \\
\hline LOTL1 does not Granger Cause LBRAKM1 & 50 & 0.11683 & 0.8900 \\
\hline LBRAKM1 does not Granger Cause LOTL1 & & 0.01653 & 0.9836 \\
\hline LATMKM1 does not Granger Cause LBRAD1 & 49 & 0.05998 & 0.9419 \\
\hline LBRAD1 does not Granger Cause LATMKM1 & & 11.2261 & 0.0001 \\
\hline LATMD1 does not Granger Cause LBRAD1 & 49 & 0.05224 & 0.9492 \\
\hline
\end{tabular}


Moïse Bigirimana, Xu Hongyi

Research on Relationship between Financial Inclusion and Economic Growth of Rwanda: Evidence from

Commercial Banks with ARDL Approach

\begin{tabular}{|c|c|c|c|}
\hline \multicolumn{2}{|l|}{ LBRAD1 does not Granger Cause LATMD1 } & 10.9240 & 0.0001 \\
\hline LLACD1 does not Granger Cause LBRAD1 & 50 & 0.09494 & 0.9096 \\
\hline \multicolumn{2}{|l|}{ LBRAD1 does not Granger Cause LLACD1 } & 4.27167 & 0.0200 \\
\hline LOTDP1 does not Granger Cause LBRAD1 & 50 & 2.93081 & 0.0636 \\
\hline \multicolumn{2}{|l|}{ LBRAD1 does not Granger Cause LOTDP1 } & 2.22517 & 0.1198 \\
\hline LOTL1 does not Granger Cause LBRAD1 & 50 & 0.07187 & 0.9308 \\
\hline \multicolumn{2}{|l|}{ LBRAD1 does not Granger Cause LOTL1 } & 0.00158 & 0.9984 \\
\hline LATMD1 does not Granger Cause LATMKM1 & 49 & 4.59461 & 0.0154 \\
\hline \multicolumn{2}{|l|}{ LATMKM1 does not Granger Cause LATMD1 } & 4.46010 & 0.0172 \\
\hline LLACD1 does not Granger Cause LATMKM1 & 49 & 1.27014 & 0.2909 \\
\hline \multicolumn{2}{|l|}{ LATMKM1 does not Granger Cause LLACD1 } & 3.05354 & 0.0573 \\
\hline LOTDP1 does not Granger Cause LATMKM1 & 49 & 2.94759 & 0.0629 \\
\hline \multicolumn{2}{|l|}{ LATMKM1 does not Granger Cause LOTDP1 } & 3.60674 & 0.0354 \\
\hline LOTL1 does not Granger Cause LATMKM1 & 49 & 0.30334 & 0.7399 \\
\hline \multicolumn{2}{|l|}{ LATMKM1 does not Granger Cause LOTL1 } & 1.84394 & 0.1702 \\
\hline LLACD1 does not Granger Cause LATMD1 & 49 & 1.26936 & 0.2911 \\
\hline \multicolumn{2}{|l|}{ LATMD1 does not Granger Cause LLACD1 } & 2.86424 & 0.0677 \\
\hline LOTDP1 does not Granger Cause LATMD1 & 49 & 2.75521 & 0.0746 \\
\hline \multicolumn{2}{|l|}{ LATMD1 does not Granger Cause LOTDP1 } & 3.58046 & 0.0363 \\
\hline LOTL1 does not Granger Cause LATMD1 & 49 & 0.31533 & 0.7312 \\
\hline \multicolumn{2}{|l|}{ LATMD1 does not Granger Cause LOTL1 } & 1.76704 & 0.1827 \\
\hline LOTDP1 does not Granger Cause LLACD1 & 50 & 2.39624 & 0.1026 \\
\hline \multicolumn{2}{|l|}{ LLACD1 does not Granger Cause LOTDP1 } & 2.74491 & 0.0750 \\
\hline LOTL1 does not Granger Cause LLACD1 & 50 & 0.87565 & 0.4236 \\
\hline \multicolumn{2}{|l|}{ LLACD1 does not Granger Cause LOTL1 } & 2.60951 & 0.0847 \\
\hline LOTL1 does not Granger Cause LOTDP1 & 50 & 1.90321 & 0.1609 \\
\hline \multicolumn{2}{|l|}{ LOTDP1 does not Granger Cause LOTL1 } & 3.13334 & 0.0532 \\
\hline
\end{tabular}

\subsection{Results of the diagnostic test}

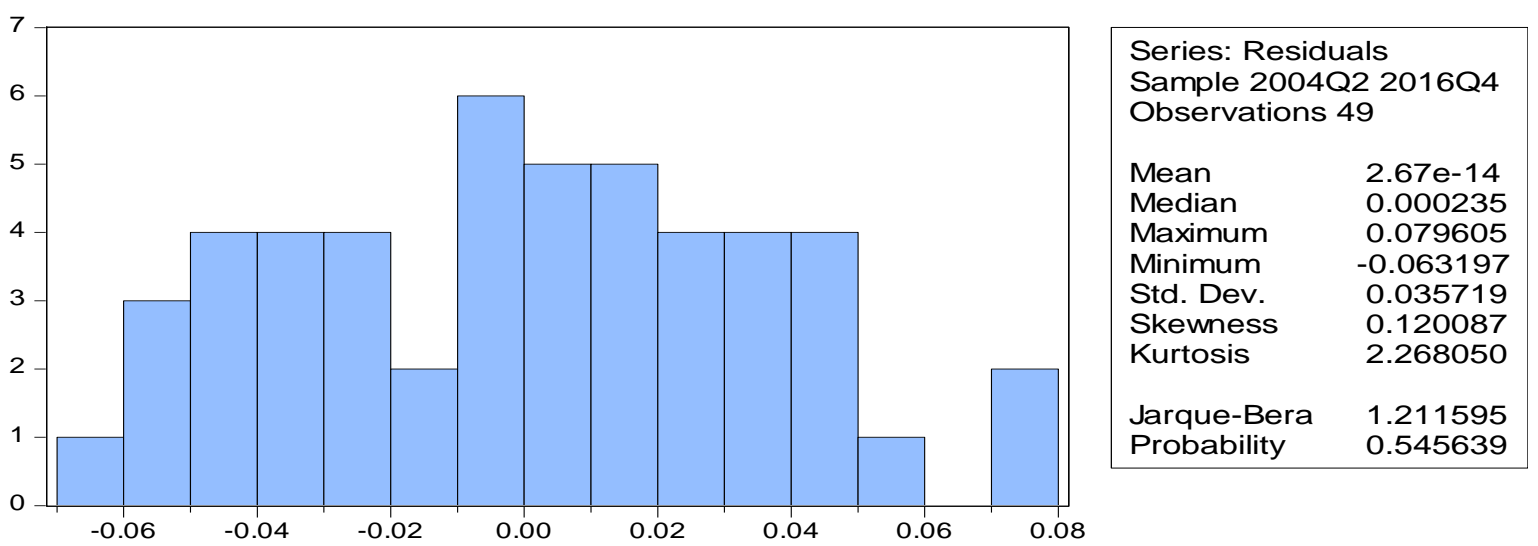

Figure 1: Jarque-bera test (Normality test)

The assumptions of this test are as follows: Ho (null hypothesis): The residuals are normally distributed.

$\mathrm{H} 1$ : The residuals are not normally distributed.

The null hypothesis is rejected when the probability is less than $10 \%$. The null hypothesis is not rejected i.e. residuals are normally distributed because the probability of $54.56 \%$ is greater than the significant level of $10 \%$.

\subsection{Results of serial correlation}

Table 4: Breusch-Godfrey Serial Correlation LM Test 
Moïse Bigirimana, Xu Hongyi

Research on Relationship between Financial Inclusion and Economic Growth of Rwanda: Evidence from Commercial Banks with ARDL Approach

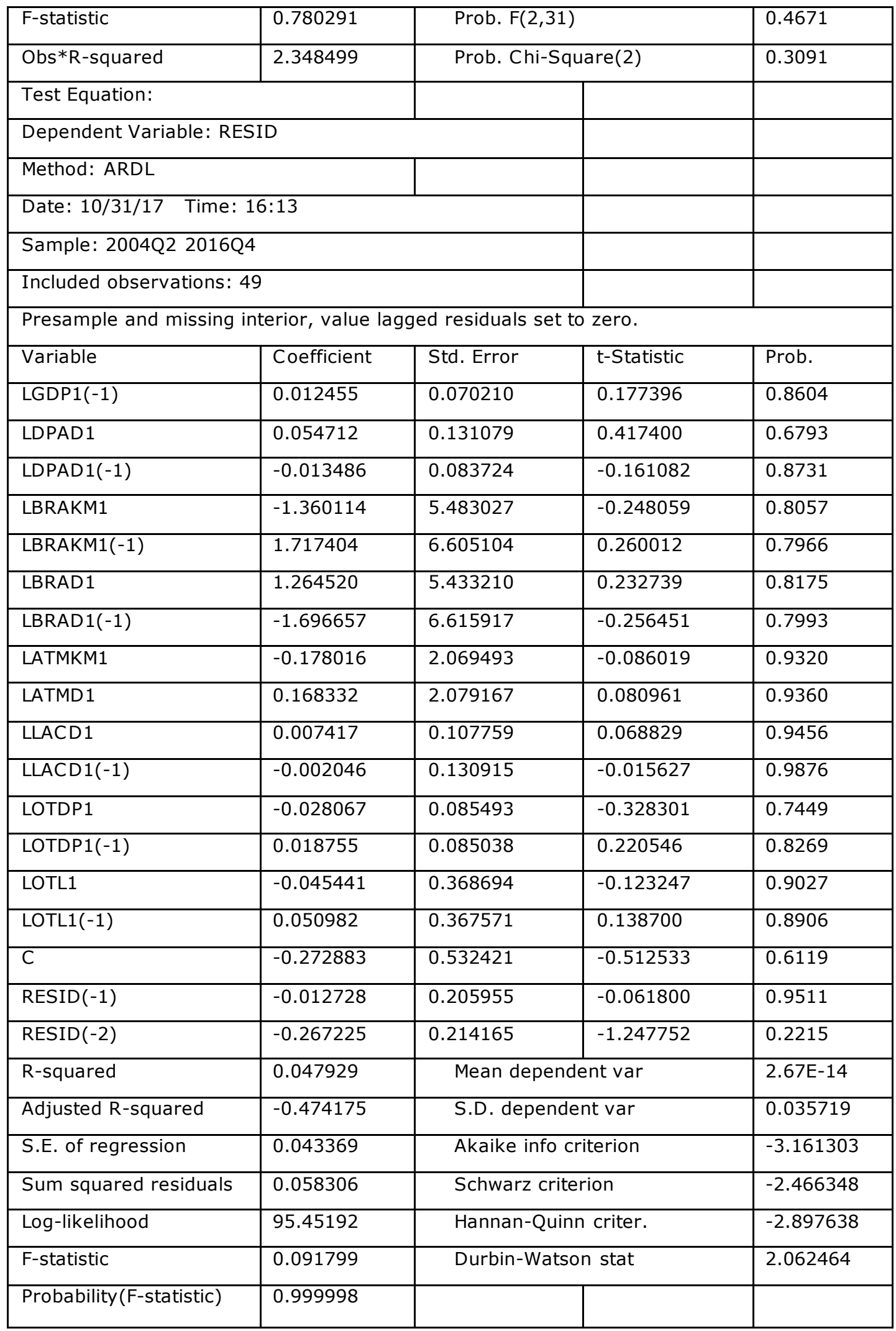

Ho: No serial correlation (errors are not correlated).

$\mathrm{H} 1$ : There is a serial correlation. 
The results show that there is no serial correlation up to the 16 th lag because all probabilities are more than $10 \%$ level of significance under correlogram of residuals squared and correlogram -q-statistics. Our results show that error terms are not serially correlated.

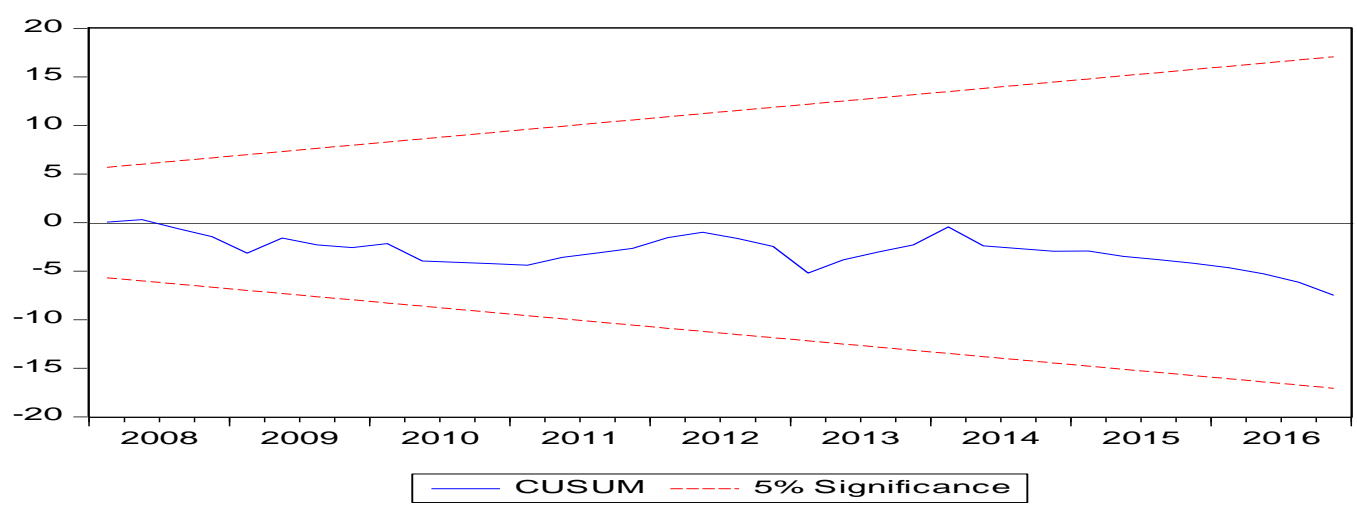

Figure 2: Stability test

Figure 2 shows that the CUSUM plot cross the $5 \%$ critical lines. Therefore, we can safely conclude that the estimated parameters for the short-dynamics and long-run of the gross domestic products in Rwanda are stable.

\section{Conclusion and Recommendations}

The objective of this research is to study the relationship between financial inclusion and economic growth of Rwanda. We used different financial inclusion indicators taking into account only commercial banks. Our research covers 13 years from 2004 to 2016. We applied ARDL approach and Granger causality tests in this research.

The results of $A R D L$, the bound test for co-integration test reveal that there is long-run relationship between Gross Domestic Product, Automated teller Machines per adult people, Automated teller Machines per square km, Bank branches per adult people, Branches per square $\mathrm{km}$, deposits accounts per adults people, loan accounts per adults people, Outstanding loans, and Outstanding deposits per adults people at 5 percent level of significance. The calculated $\mathrm{F}$ statistic of 6.100343 is bigger than the upper bound critical value of 3.97; therefore the null hypothesis of no co-integration is rejected even bellow at $1 \%$ level of significance which testifies the presence of a long-run relationship between GDP and all explanatory variables.

Based on the results of ARDL bounds test, all the variables jointly affect the dependent variable at $1 \%$ in the long-run. Note that in the short-run the following variables are significant: deposit accounts per adults people, branch per square $\mathrm{km}$, branches per adults people, loan accounts per adults people, outstanding deposits per adults people and outstanding loans. Automated teller machines per square $\mathrm{km}$ and branches per square $\mathrm{km}$ are not significant, but we hope that they can be adjusted quarterly as error correction term has the negative sign.

Granger causality test showed the following results: Loan Accounts per Adults People (LACAD) does not Granger cause Gross domestic Product (GDP) versus GDP does not Granger cause LACAD. Since P-value (.0029) is less than .05 we conclude that causality runs from GDP to LACAD, meaning that direction of causality runs from GDP to LACAD. But LACAD does not Granger cause GDP in Rwanda as associated P-value is not significant. Outstanding loans does not Granger cause Gross Domestic product versus Gross Domestic product does not Granger cause Outstanding loans showed unidirectional causality where Outstanding loans Granger cause Gross Domestic Products. This is in line with what theories show that loans cause 
economic growth. We found that there is bidirectional causality between deposits accounts and branches per square $\mathrm{km}$.

ARDL results showed that all the dependent varia bles explain independent variable. On the basis of ARDL and Granger causality test, we find that financial inclusion cause economic growth in Rwanda. As the results of our study revealed that commercial banks loans contributes to economic growth of Rwanda, the government of Rwanda should set policies that ease loan access for more people to take loans. This would boost financial inclusion as well as economic growth.

\section{References}

- Adel, I., \& Imen, G. (2018). Does public expenditure on education promote Tunisian and Moroccan GDP per capita? ARDL approach. The Journal of Finance and Data Science, 1-13.

- Anwar, S., \& Sun, S. (2011). Financial development, foreign investment and economic growth in Malaysia. Journal of Asian Economics, 22(4), 335-342. Crossref

- Bahmani-oskooee, M., Halicioglu, F., \& Hegerty, S. W. (2016). Mexican bilateral trade and the J-curve: An application of the nonlinear ARDL model. Economic Analysis and Policy. Crossref

- Baldi, Guido and Sipilova, V. (2014). How Big Are the Employment Effects of Microloans? Evidence from a Case Study in Latvia. Theoretical and Practical Research in Economic Field, $\mathrm{V}(1), 17-31$.

- Bayero, M. A. (2015). Effects of cashless economy policy on financial inclusion in Nigeria: An exploratory study. Procedia -Social and Behavioral Sciences Global Conference on Business \& Social Science, 172, 49-56. Crossref

- Beck, T., DemirgüÇ-Kunt, A., \& Maksimovic, V. (2005). Financial and Legal Constraints to Growth: Does Firm Size Matter? The Journal of Finance, 60(1), 137-177. Crossref

- Beck, T., Demirguc-Kunt, A., \& Martinez Peria, M. S. (2007). Reaching out: Access to and use of banking services across countries. Journal of Financial Economics, 85(1), 234-266. Crossref

- Bencivenga, V., \& Smith, B. (1991). Financial intermediation and endogenous growth. The Review of Economic Studies, 58(2), 195-209. Crossref

- Berhane, G., \& Gardebroek, C. (2011). Does microfinance reduce rural poverty? Evidencebased on household panel data from northern Ethiopia. American Journal of Agricultural Economics, 93(1), 43-55. Crossref

- Bildirici, M., \& Ozaksoy, F. (2017). The relationship between woody biomass consumption and economic growth : Nonlinear ARDL and causality. Journal of Forest Economics, 27, 6069. Crossref

- Boukhatem, J., \& Ben Moussa, F. (2018). The effect of Islamic banks on GDP growth: Some evidence from selected MENA countries. Borsa Istanbul Review. Crossref

- Chakraborty, S., \& Ray, T. (2006). Bank-based versus market-based financial systems: A growth-theoretic analysis. Journal of Monetary Economics, 53(2), 329-350. Crossref

- Claessens, S., \& Laeven, L. (2003). Financial Development, Property Rights, and Growth. Journal of Finance, 58(6), 2401-2436. Crossref

- Daly, S., \& Frikha, M. (2016). Banks and economic growth in developing countries: What about Islamic banks ? Cogent Economics\&finance, 4(1), 1-26.

- Demirgüc-Kant, A., \& Klapper, L. (2012). Financial Inclusion in Africa: An Overview. The World Bank: Policy Research Working Paper 6088, (June). Crossref

- Demirguc-Kunt, A., Klapper, L., Singer, D., \& Van Oudheusden,P. (2015). The Global Findex Database 2014: Measuring Financial Inclusion around the World. World Bank Policy Research Working Paper, 7255(April. Crossref 
- Diniz, E., Birochi, R., \& Pozzebon, M. (2012). Triggers and barriers to financial inclusion: The use of ICT-based branchless banking in an Amazon county. Electronic Commerce Research and Applications, 11(5), 484-494. $\underline{\text { Crossref }}$

- Donou-Adonsou, F., \& Sylwester, K. (2017). Growth effect of banks and microfinance: Evidence from developing countries. Quarterly Review of Economics and Finance, 64, 44-56. Crossref

- Du, W. (2011). The investigation on the relationship between the problem of long-term loan and economic growth. China Finance Review International, 1(2), 187-198. Crossref

- Durusu-Ciftci, D., Ispir, M. S., \& Yetkiner, H. (2016). Financial Development and Economic Growth: Some Theory and More Evidence. Journal of Policy Modeling.

- Fousekis, P., Katrakilidis, C., \& Trachanas, E. (2015). Vertical price transmission in the US beef sector: Evidence from the nonlinear ARDL model. Economic Modelling. Crossref

- Fungáčová, Z., \& Weill, L. (2013). Does competition influence bank failures? Evidence from Russia. Economics of Transition, 21(2), 301-322. Crossref

- Goh, S. K., Sam, C. Y., \& Mcnown, R. (2017). Re-examining Foreign Direct Investment, Exports, and Economic Growth in Asian Economies Using a Bootstrap ARDL Test for Cointegration. Journal of Asian Economics. Crossref

- Kim, D., Yu, J., \& Hassan, M. K. (2018). Research in International Business and Finance Financial inclusion and economic growth in OIC countries. Research in International Business and Finance, 43, 1-14. Crossref

- King, R., \& Levine, R. (1993). Finance and Growth Schumpeter Might Be Right. The Quarterly Journal of Economics, 108(3), 717-737. $\underline{\text { Crossref }}$

- Kodan, A. S. K., \& Chhikara, K. S. (2013). A Theoretical and Quantitative Analysis of Financial Inclusion and Economic Growth. Management and Labour Studies, 38(1-2), 103-133.

- Liang, H. Y., \& Reichert, A. K. (2012). The impact of banks and non-bank financial institutions on economic growth. Service Industries Journal, 32(5), 699-717. Crossref

- Mandel, B. R., \& Seydl, J. (2016). Credit conditions and economic growth : Recent evidence from US banks. Economics Letters, 147, 63-67. Crossref

- Masoud, N., \& Hardaker, G. (2012). The impact of financial development on economic growth: Empirical analysis of emerging market countries. Studies in Economics and Finance, 29(3), 148-173. Crossref

- Murthy, V. N. R., \& Okunade, A. A. (2016). Determinants of U.S. Health Expenditure: Evidence from autoregressive distributed lag ( ARDL ) approach to cointegration. Economic Modelling, 59, 67-73. Crossref

- Naceur, S. Ben, Barajas, A., \& Massara, A. (2015). Can Islamic Banking Increase Financial Inclusion? International Monetary Fund, WP/15/31, 1-41. Crossref

- Onaolapo, A. R. (2015). Effects of financial inclusion on the economic growth of Nigeria (1982-2012). International Journal of Business and Management Review, 3(8), 11-28.

- Park, C., \& Mercado, R. V. (2015). Financial Inclusion, Poverty, and Income Inequality in Developing Asia.ADB ECONOMICS WORKING PAPERS SERIES. ADBEconomics Working Paper Series, (426). $\underline{\text { Crossref }}$

- Pesaran, M. H., Shin, Y., \& Smith, R. J. (2001). Bounds testing approaches to the analysis of level relationships. Journal of Applied Econometrics, 16(3), 289-326. Crossref

- Rousseau, P. L., \& D'Onofrio, A. (2013). Monetization, financial development, and growth: Time series evidence from 22 Countries in Sub-Saharan Africa. World Development, 51, 132153. Crossref

- Sarma, M. (2008). Index of Financial Inclusion. Indian Council for Research on International Economic Relations Working Paper No 215, 1-26.

- Sehrawat, M., \& Giri, A. K. (2012). The impact of financial development on economic growth. Studies in Economics and Finance, 29(3), 148-173. Crossref

- Sehrawat, M., \& Giri, A. K. (2016). Panel data analysis of financial development, economic growth, and rural-urban income inequality. International Journal of Social Economics, 43(10), 998-1015. Crossref 
- Shahbaz, M., \& Mafizur Rahman, M. (2014). Exports, financial development and economic growth in Pakistan. International Journal of Development Issues, 13(2), 155-170. Crossref

- Shahbaz, M., Rehman, I. U., \& Muzaffar, A. T. (2015). Re-visiting financial development and economic growth nexus: The role of capitalization in Bangladesh.South African Journal of Economics, 83(3), 452-471. Crossref

- Shahzad, M., Jan, A. U., Ali, S., \& Ullah, R. (2018). Supply response analysis of tobacco growers in Khyber Pakhtunkhwa: An ARDL approach. Field Crops Research, 218(January), 195-200. $\underline{\text { Crossref }}$

- Shan, J. Z., Morris, A. G., \& Sun, F. (2001). Financial Development and Economic Grow th: An Egg-and-Chicken Problem? Review of International Economics, 9(3), 443-454. Crossref

- Sharma, D. (2016). Nexus between financial inclusion and economic growth: evidence from the emerging Indian economy. Journal of Financial Economic Policy, 8(1), 1-10. Crossref

- Tursoy, T., \& Faisal, F. (2017). The impact of gold and crude oil prices on stock market in Turkey: Empirical evidences from ARDL bounds test and combined cointegration. Resources Policy, (October), 0-1. Crossref

- Vaithilingam, S., Guru, B. K., \& Shanmugam, B. (2003). Bank Lending and Economic Growth in Malaysia Bank Lending and Economic Growth in Malaysia. Journal of Asia-Pacific Business, 5, 51-69. Crossref

- Valickova, P., Havranek, T., \& Horvath, R. (2015). Financial development and economic growth: A meta-analysis. Journal of Economic Surveys, 29(3), 506-526. Crossref

- Zins, A., \& Weill, L. (2016).The determinants of financial inclusion in Africa. Review of Development Finance, 6(1), 46-57. $\underline{\text { Crossref }}$ 